\title{
JUURNAL.RU
}

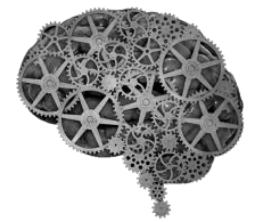

COMPANY GROUP "INTELLEKT"

Кубликова Ю.А. Кубанский государственный технологический университет Краснодар, Россия

doi: 10.18411/lj2016-6-1-13

\section{Развитие условий поставки товаров в международном сообщении}

В статье рассматриваются основные международные документы, регулирующие международные поставки товаров, прослеживаются основные направления совершенствования правовых основ и унификации правил международного торгового оборота, рассматривается возможность создания единой глобальной конвенции, регулирующей международные поставки товаров.

Международная поставка товаров является одним из способов экономического сотрудничества государств. Поскольку эта деятельность затрагивает экономические интересы многих стран, она подчинена общим правилам, которые составляют правовую основу международного сотрудничества. Деятельности, связанной с международной поставкой товаров,посвящены многие международные нормативно-правовые документы, наиболее значимыми которых являются Конвенция о договорах международной купли-продажи (поставки) товаров 1980 г. («Венская Конвенция»), сборник толкований международных терминов Инкотермс, Принципы международных коммерческих договоров УНИДРУА и др.

Венская Конвенция является одним из базовых нормативноправовыхдокументов, регулирующих порядок заключения международного договора купли-продажи (поставки) товаров и устанавливающая права и обязанности продавца и покупателя, вытекающие из такого договора.Венская 
Конвенция является обязательным к применению документом при заключении международных договоров поставки товаров.

В отличии от Венской Конвенции,базисные условияИнкотермс и Принципы УНИДРУА не являются международным договором, поэтому не обращены к государствам и не предполагают какого-либо одобрения с их стороны, не обладают юридической силой. Применение осуществляется на добровольной основе по соглашению сторон договора, Хотя в некоторых странах их применение обязательно по закону. Например, согласно п. 4 ст. 265 ХК Украины при определении условий договора необходимо применять правила Инкотермс [3].

Однако, с момента принятия Венской Конвенции прошло уже около 35 лет. В сфере международного коммерческого оборота произошли масштабные изменения. Появление интернета и новых технологий, активизация международной торговли и усиливающаяся экономическая взаимозависимость стран мира, а с ними и новые сферы договорных отношений, произошедшие интеграционные процессы поставили задачу совершенствования правовых основ и унификации правил международного торгового оборота. Унификация правил позволит облегчить процесс заключения и исполнения международных договоров купли-продажи (поставки) грузов. Благодаря унификации стираются различия в регулировании отношений по вопросам внешнеэкономической деятельности в национальном законодательстве государств[1].

В связи с этим уже неоднократно выдвигались предложения по созданию универсальной конвенции в сфере международного коммерческого оборота, которая заключала бы в себе самые разные вопросы договорного права.

Многими авторами, которые выступали за работу в сфере создания новой конвенции, отмечалось, что в основу разработки данной конвенции могут лечь Принципы УНИДРУА. Так, например, американский ученый Х. Габриэль в своей статье приходит к выводу, что в случае осуществления попытки, направленной на создание масштабной конвенции в сфере международного 
коммерческого оборота, необходимо опираться на исходный продукт УНИДРУА, который предусматривает различные методы работы, и взять его за основу для разработки соглашения о глобальном договорном праве в рамках Комиссии ООН по праву международной торговли ЮНСИТРАЛ [2].

Переговоры по созданию подобной конвенции идут уже в течение довольно длительного времени. Однако к настоящему времени результатов таких переговоров пока не достигнуто.С одной стороны, новая конвенция открыла бы новые перспективы по созданию Глобального кодекса международной торговли. $\mathrm{C}$ другой, на пути разработки конвенции разработчики могут столкнуться с некоторыми препятствиями:разработка подобного рода конвенции потребует большого вложения труда разработчиков и времени в силу того, что конвенция будет затрагивать различные вопросы договорного права, которые в разных странах имеют различное содержание.

Более того, если даже представить, что данный процесс будет проходить успешно и делегации из разных стран смогут договориться по содержанию данного договора, то он потребует очень большого финансирования и затрат, что сейчас для ЮНСИТРАЛ невозможно.

К тому же, любой международный договор, в отличие от средств негосударственного регулирования обязательно требует, чтобы государства выразили свою волю путем ратификации данного договора и введение его в свое внутреннее законодательство. А с учетом того, что за 35 лет к Венской конвенции, которая обладает достаточной узкой сферой регулирования, присоединилось 80 государств, и этот процесс был очень длительным и не происходил так уж безболезненно. Так, например, Великобритания и Северная Ирландия до сих пор не являются участниками данной конвенции, а Япония присоединилась только в 2008 г.

Следовательно, новая конвенция, даже факт создания, которой, уже вызывает массу споров, скорее всего, не сможет набрать требуемое число 
ратификационных грамот. Поэтому она или не вступит в силу или будет действовать для незначительного числа государств.

Все вышеперечисленное свидетельствует о том, что на сегодняшний вряд ли можно еще пока говорить о разработке такой глобальной конвенции. Однако необходимо еще раз подчеркнуть, что сегодня в сфере международного коммерческого оборота на очень высоком уровне всерьез задумались о возможности разработать Глобальную конвенцию, которая будет включать в себя весь спектр вопросов, касающихся договорных отношений. Причем именно Принципы УНИДРУА, которые хотя и не обладают обязательной силой, аналогичной силе международных конвенций, и представляют собой негосударственный доктринальный свод общих правил международной торговли, появившийся на международном уровне благодаря деятельности ученых, без привлечения официальных структур власти - смогут сыграть решающую роль в этом грандиозном будущем проекте.

\section{Литература:}

1. Иванова Т.Н. Современные тенденции унификации торговых обычаев во внешнеэкономической деятельности и международных перевозках. // Вестник Международного института экономики и права. -2013. - №1. - С. 84-89.

2. Алимова Я.О. Принципы УНИДРУА - как источник будущей новой конвенции в сфере договорного права. Миф или реальность? // Бизнес в законе. Экономико-юридический журнал. - 2014. - №3. - С. 15-19.

3. Аксенов А.Г. Обычаи, применяемые к договору международной куплипродажи товаров между субъектами предпринимательской деятельности стран СНГ // Вестник Нижегородского университета им. Н.И. Лобачевского. - 2014. - №3-2. - С. 22-29. 